\title{
Papers
}

\section{Calprotectin inhibits matrix metalloproteinases by sequestration of zinc}

\author{
B Isaksen, M K Fagerhol
}

\begin{abstract}
BackgroundlAims-Calprotectin, $36 \mathrm{kDa}$ protein present in neutrophil cytoplasm, has antimicrobial and apoptosis inducing activities, which are reversed by the addition of zinc. Matrix metalloproteinases (MMPs), a family of zinc dependent enzymes, are important in many normal biological processes including embryonic development, angiogenesis, and wound healing, but also pathological processes such as inflammation, cancer, and tissue destruction. The aim of this study was to investigate whether calprotectin can inhibit MMP activity, and whether such inhibition could be overcome by the addition of zinc.

Methods-MMP activity was measured by the degradation of substrates precoated on to microwells, and visualised by Coomassie blue staining of residual substrate. Seven metalloproteinases (MMP-1, MMP-2, МMP-3, МMP-7, МMP-8, MMP-9, and MMP-13) were tested against two substrates: gelatin and $\alpha$-casein.

Results-All MMPs except MMP-1 were active against gelatin, whereas MMP-7 was the only enzyme active against $\alpha$-casein. The addition of calprotectin inhibited the activity of all the MMPs, but different concentrations of the protein, from $0.3 \mu \mathrm{M}$ to $>11 \mu \mathrm{M}$, were necessary to produce a $50 \%$ inhibition of the MMPs. Inhibition by calprotectin was largely overcome by the addition of zinc.

Conclusions-The findings suggest that calprotectin inhibits MMPs by sequestration of zinc. The data also suggest that MMPs have different affinities for zinc and that calprotectin has a lower zinc affinity than the MMPs.

(7 Clin Pathol: Mol Pathol 2001;54:289-292)
\end{abstract}

Department of
Immunology and Transfusion Medicine, Ullevaal University Hospital, Kirkeveien 166, 0407 Oslo, Norway B Isaksen

M K Fagerhol

Correspondence to: Dr Isaksen

barbro.isaksen@ulleval.no

Accepted for publication 7 June 2001 development of malignant disease and death. Even lower organisms, such as Gram positive and negative bacteria, produce similar enzymes, which can cause tissue destruction directly via activation of our own matrix metalloproteinases (MMPs), or release of membrane anchored cytokines or cytokine receptors. ${ }^{2}$

Calprotectin, a calcium binding $36 \mathrm{kDa}$ protein constituting more than $60 \%$ of total soluble cytosol proteins in human neutrophil granulocytes, ${ }^{34}$ is antimicrobial ${ }^{5-7}$ probably by means of local zinc deprivation. Sohnle et al have shown recently that calprotectin contains a high affinity zinc binding site, which requires the presence of both types of polypeptide chain. ${ }^{8}$ It is well known that zinc is vital even for bacteria, and the release of large amounts of calprotectin may contribute to the inhibition of microbial proliferation and the inflammation and tissue destruction that they can cause. Calprotectin can even cause apoptosis in human and animal tumour cells in vitro. ${ }^{9}$

Our study was designed to test the hypothesis that calprotectin may also inhibit human MMPs, including some involved in tumour invasiveness. ${ }^{10}{ }^{11}$ For this purpose, we used the gelatinolytic microwell assay described by Rucklidge and Milne, ${ }^{12}$ with some modifications. This assay allowed us to test the possible inhibition of MMPs by calprotectin and to test the hypothesis that calprotectin exerts its activity by sequestration of zinc. The use of zymograms (the most common way to test MMP activity) was not an option because the gels contain zinc, which was the crucial parameter to be tested.

\section{Materials and methods}

COATING OF MICROWELLS

Stock solutions containing $1 \mathrm{mg} / \mathrm{ml}$ of the two substrates were made as follows: $20 \mathrm{mg}$ of gelatin (porcine skin 300 Bloom; SigmaAldrich, St Louis, Missouri, USA) was dissolved in $17 \mathrm{ml}$ phosphate buffered saline (PBS), followed by the addition of $3 \mathrm{ml}$ paraformaldehyde $(1 \mathrm{mg} / \mathrm{ml}$ in PBS). The solution was stirred for 15 minutes at $70^{\circ} \mathrm{C}$ before use. For $\alpha$-casein (C-6780; SigmaAldrich), $20 \mathrm{mg}$ was dissolved in $16 \mathrm{ml}$ PBS, and $4 \mathrm{ml}$ of paraformaldehyde was added before stirring at $70^{\circ} \mathrm{C}$. For coating of microwells (MaxiSorp; Nunc, Roskilde, Denmark), the substrate stock solutions were diluted further in PBS so that by adding $80 \mu \mathrm{l}$ each well would contain $40 \mu \mathrm{g}$ gelatin or $50 \mu \mathrm{g} \alpha$-casein. The wells were allowed to dry at $51^{\circ} \mathrm{C}$ for two to three hours in an incubator/dryer IS 80 (Sebia, Issy-les Moulineaux, France), washed 
four times for 20 minutes with $300 \mu \mathrm{l}$ distilled water, and stored overnight in distilled water at $4^{\circ} \mathrm{C}$. The next day the water was removed, the wells were dried at $37^{\circ} \mathrm{C}$ for 30 minutes, covered with a plate sealer (Nunc), and stored at $-20^{\circ} \mathrm{C}$ until use.

ACTIVATION OF MMPS

MMPs from R\&D systems (Abingdon, UK) were dissolved in TNC buffer $(50 \mathrm{mM}$ Tris, $150 \mathrm{mM} \mathrm{NaCl}, 5 \mathrm{mM} \mathrm{CaCl}, 1 \mu \mathrm{M} \mathrm{ZnCl}_{2}$, $0.01 \% \mathrm{BRIJ} 35, \mathrm{pH} 7.6)$ to give a concentration of $100 \mu \mathrm{g} / \mathrm{ml}$, and stored at $-20^{\circ} \mathrm{C}$. MMPs from Chemicon International (Temecula, California, USA) were supplied as frozen liquids, and kept at $-20^{\circ} \mathrm{C}$ until use. The MMPs were diluted in TNC buffer to a stock solution of $4 \mu \mathrm{g} / \mathrm{ml}$, activated by the addition of $2 \mathrm{mM}$ APMA (aminophenyl mercuric acetate) in DMSO (dimethyl sulphoxide), and incubated for 24 hours at $37^{\circ} \mathrm{C}$.

TESTING OF MMP ACTIVITY

The activated stock solutions of MMPs were diluted in TNC buffer, containing $0.2 \mathrm{mM}$ APMA/DMSO, to give concentrations between 0 and $400 \mathrm{ng} / \mathrm{ml}$, and $200 \mu \mathrm{l}$ was added to each substrate coated microwell. The wells were covered with a plate sealer and incubated for 22 hours at $37^{\circ} \mathrm{C}$.

After incubation, the wells were washed three times for 10 minutes with distilled water and tapped dry.

COOMASSIE BLUE STAINING

Residual substrate was stained by incubation with $0.25 \%$ Coomassie brilliant blue (SigmaAldrich) in acetic acid/methanol/water (1/ $10 / 10 \mathrm{vol} / \mathrm{vol} / \mathrm{vol}$ ) for $30 \mathrm{minutes}$ at room temperature, $200 \mu 1 /$ well. The wells were washed three times for 10 minutes, and once for 30 minutes with distilled water.

To obtain homogenous Coomassie blue staining, residual substrate was brought into solution by the addition of $100 \mu \mathrm{l} 6 \mathrm{M} \mathrm{HCl}$, shaking for one to two minutes at $500 \mathrm{rpm}$, and the addition of $150 \mu \mathrm{l} 2 \mathrm{M} \mathrm{NaOH}$. The optical density was read at $595 \mathrm{~nm}$ on an $\mathrm{El}_{\mathrm{x}} 800$ microplate reader (Bio-Tek instruments, Winooski, Vermont, USA).

\section{INHIBITORY EFFECT OF CALPROTECTIN}

Calprotectin, purified from human leucocytes as described by Dale et $a l,{ }^{13}$ was added to give final concentrations of $0-11 \mu \mathrm{M}$ to test for inhibition of MMP activity.

A zinc concentration of $1 \mu \mathrm{M}$ was used in the TNC buffer. This provided enough zinc for the MMPs, and was the concentration recommended for activating the enzymes. To investigate whether an excess of zinc could reverse the effect of calprotectin, a concentration of $100 \mu \mathrm{M}$ was used.

\section{Results}

The activated MMPs differed with regard to the degradation of substrates. Despite giving distinct bands on zymogram gels (details not shown), MMP-1 (interstitial collagenase) was inactive against both the substrates in the

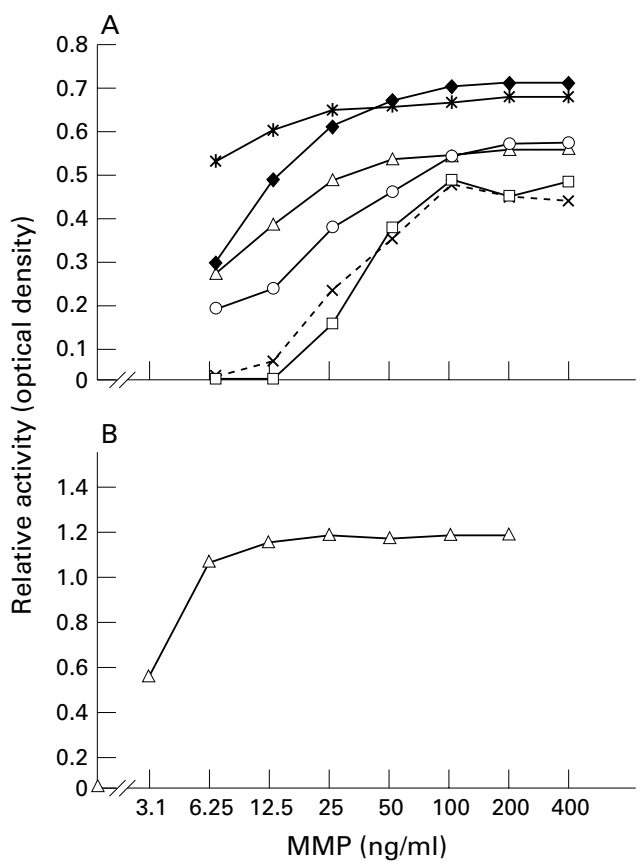

Figure 1 Degradation of $(A)$ gelatin and $(B)$ casein by matrix metalloproteinases (MMPS). Relative MMP activities against gelatin and casein, at enzyme concentrations ranging from 0 to $400 \mathrm{ng} / \mathrm{ml}$. Closed diamonds, $M M P-2$;open squares, $M M P-3$; open triangles, $M M P-7$; crosses and broken line, MMP-8; asterisks, MMP-9; open circles, $M M P-13$. The data are expressed as the optical density (OD) at $595 \mathrm{~nm}$ for the blank (no enzyme added) minus the OD of the sample wells. Each point represents the mean of duplicates.

Table 1 Matrix metalloproteinase (MMP) concentrations used for testing of inhibition by calprotectin

\begin{tabular}{lll}
\hline & Gelatin microwell assay & Casein microwell assay \\
\hline MMP-2 & $25 \mathrm{ng} / \mathrm{ml}(0.35 \mathrm{nM})$ & \\
MMP-3 & $100 \mathrm{ng} / \mathrm{ml}(1.9 \mathrm{nM})$ & \\
MMP-7 & $50 \mathrm{ng} / \mathrm{ml}(1.78 \mathrm{nM})$ & $10 \mathrm{ng} / \mathrm{ml}(0.35 \mathrm{nM})$ \\
MMP-8 & $100 \mathrm{ng} / \mathrm{ml}(1.96 \mathrm{nM})$ & \\
MMP-9 & $25 \mathrm{ng} / \mathrm{ml}(0.27 \mathrm{nM})$ & \\
MMP-13 & $100 \mathrm{ng} / \mathrm{ml}(1.9 \mathrm{nM})$ & \\
\hline
\end{tabular}

microwell assay. MMP-2 (gelatinase A), MMP-3 (stromelysin 1), MMP-7 (matrilysin), MMP-8 (collagenase 1), MMP-9 (gelatinase B), and MMP-13 (collagenase 3) were all active against gelatin, whereas MMP-7 was the only enzyme active against $\alpha$-casein (fig 1 ). The MMP activities did not vary according to whether they were obtained from R\&D systems or Chemicon International.

For testing of inhibition by calprotectin, MMP concentrations close to the inflection point (between rapidly increasing and maximum activity) were used (fig 1 ; table 1 ).

\section{INHIBITORY EFFECT OF CALPROTECTIN}

An inhibitory effect of calprotectin was seen against all activated MMPs used in these assays, and on both substrates (fig 2).

Different concentrations of calprotectin were necessary to give a $50 \%$ inhibition of the various enzymes, from $0.3 \mu \mathrm{M}$ for MMP-8 to $5 \mu \mathrm{M}$ for MMP-9 against gelatin (table 2). For MMP-7, $11 \mu \mathrm{M}$ calprotectin gave only about $30 \%$ inhibition in the gelatinolytic assay (fig 2). 


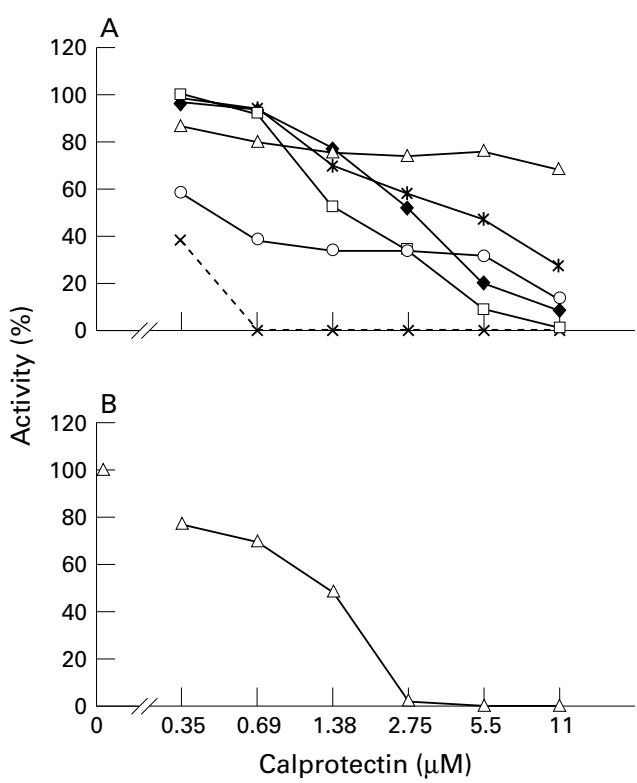

Figure 2 Inhibition of matrix metalloproteinase (MMP) activities by calprotectin in $(A)$ gelatinolytic and $(B)$ caseinolytic microwell assays. Closed diamonds, MMP-2; open squares, $M M P-3$; open triangles, $M M P-7$; crosses and broken line, $M M P-8$; asterisks, MMP-9; open circles, $M M P-13$. Inhibition is expressed as percentage activity, when $0-11 \mu \mathrm{M}$ calprotectin is present. Each point represents the mean of duplicates.

Table 2 Calprotectin concentrations giving 50\% inhibition of matrix metalloproteinase (MMP) activity

\begin{tabular}{lll}
\hline & Gelatin microwell assay & Casein microwell assay \\
\hline MMP-2 & $2.8 \mu \mathrm{M}$ & \\
MMP-3 & $1.4 \mu \mathrm{M}$ & \\
MMP-7 & $>11 \mu \mathrm{M}$ & $1.4 \mu \mathrm{M}$ \\
MMP-8 & $0.3 \mu \mathrm{M}$ & \\
MMP-9 & $5 \mu \mathrm{M}$ & \\
MMP-13 & $0.5 \mu \mathrm{M}$ & \\
\hline
\end{tabular}

Approximately $1.4 \mu \mathrm{M}$ calprotectin gave a $50 \%$ inhibition of MMP-7 in the caseinolytic assay (table 2).

EFFECTS OF ADDITION OF ZINC

As shown in fig 3, the relative degradation of casein by MMP-7 was only $10 \%$ when $11 \mu \mathrm{M}$ calprotectin and $1 \mu \mathrm{M}$ zinc were used, whereas $60 \%$ of the activity remained when $100 \mu \mathrm{M}$ zinc was used.

Figure 3 also shows the relative activities of the six MMPs against gelatin when incubated

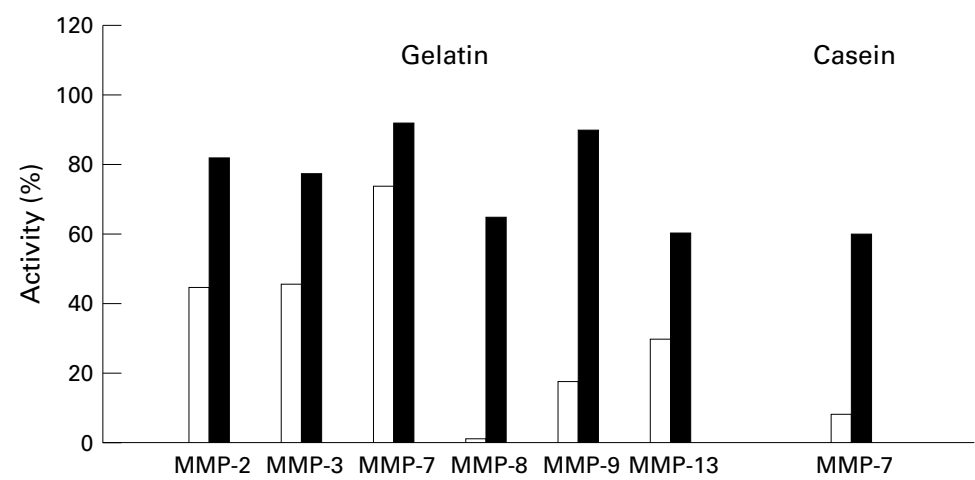

Figure 3 Relative activities of metalloproteinases in the gelatinolytic and caseinolytic microwell assays, when incubated with $11 \mu \mathrm{M}$ calprotectin and $1 \mu \mathrm{M}$ (open bars) or $100 \mu \mathrm{M}$ (closed bars) zinc. The figures are expressed as percentage activity compared with activity without calprotectin. with $11 \mu \mathrm{M}$ calprotectin and $1 \mu \mathrm{M}$ or $100 \mu \mathrm{M}$ zinc. Except for MMP-7, all enzymes were greatly inhibited by calprotectin in the gelatinolytic assay, and this inhibition was largely overcome by the addition of $100 \mu \mathrm{M}$ zinc.

\section{Discussion}

Our results show that modifications of the method described by Rucklidge and Milne allow the quantitative determination of MMP activities. This method avoids the use of radioactive isotopes and different substrates can be used. Furthermore, the assay system is simple and sensitive, allowing detection of $3 \mathrm{ng} / \mathrm{ml}$ or less. However, this method is more time consuming than a recently described method using biotinylated gelatin. ${ }^{14}$ Another aspect is that some substrates, such as collagen, may be altered and less available for enzymatic degradation as a result of the coating process or exposure to paraformaldehyde. For instance, collagen type 1 (from calf skin, Fluka, Buchs, Switzerland) was almost completely converted into gelatin, which was shown by the fact that it was rapidly degraded by trypsin (data not shown).

MMPs are activators of a broad range of cytokines, including interleukin 1, tumour necrosis factor $\alpha$, Fas ligand, and transforming growth factor $\beta,{ }^{15-19}$ and thereby play important roles in regulating processes such as acute and chronic inflammation, tumour cell invasion, apoptosis, and macrophage chemotaxis. Calprotectin may affect various pathophysiological processes by competing with MMPs for zinc. Our study revealed that calprotectin inhibits the activity of all the enzymes tested, and that this inhibition was overcome by the addition of zinc. A higher concentration of calprotectin was necessary to inhibit some metalloproteinases than others, regardless of the substrate. In the gelatinolytic assay, MMP-3, MMP-8, and MMP-13 needed a 200-700 times molar excess of calprotectin to give a $50 \%$ inhibition. By comparison, up to a 18000 times molar excess was necessary to give a similar inhibition of MMP-2 and MMP-9.

These results suggest that MMPs have different affinities for zinc, and that calprotectin has an even lower affinity, because a large excess was necessary for inhibition.

Structurally, MMP-2, MMP-3, MMP-8, MMP-9, and MMP-13 have one catalytic domain containing the zinc binding site. In addition, MMP-2 and MMP-9 have one zinc binding site closer to the C-terminal, suggesting a higher capacity for binding of zinc. MMP-7, the smallest of the proteins, also has one catalytic domain. ${ }^{1}$ Nonetheless, a much higher concentration of calprotectin was needed to inhibit this enzyme than MMP-3, MMP-8, or MMP-13, which suggests that MMP-7 has a higher affinity constant for zinc.

The metalloproteinases are totally dependent on zinc for their enzymatic activities, ${ }^{1}$ and our results support the hypothesis that some biological effects of calprotectin are linked to its sequestration of zinc. Sohnle et al showed that calprotectin inhibits microbial activity via a zinc deprivation mechanism, ${ }^{80}$ and it has 
also been shown that the apoptosis inducing activities of calprotectin were inhibited by the addition of micromolar concentrations of zinc. $^{21}$ The concentrations of calprotectin needed to inhibit the MMPs in vitro may be biologically relevant. During bacterial infections, up to $120 \mathrm{ng} / \mu \mathrm{l}$ has been found in plasma. ${ }^{4}$ The release of calprotectin from neutrophils in human peripheral blood may give a concentration of about $20 \mathrm{ng} / \mu \mathrm{l}$ plasma, based on a content of $5 \mathrm{pg}$ calprotectin/cell, ${ }^{22}$ and $4 \times 10^{9}$ neutrophils/litre blood. Local accumulation of granulocytes corresponding to five times the normal may provide $5 \mu \mathrm{M}$ calprotectin, which would lower the activity of most of the enzymes by $50 \%$ or more, if their concentrations in vivo were similar to those used in vitro. The enormous numbers of leucocytes seen at sites of inflammation have the potential to provide several thousand times higher concentrations of calprotectin.

1 Nagase H, Woessner JF, Jr. Matrix metalloproteinases. F Biol Chem 1999;274:21491-4.

2 Vollmer P, Walev I, Rose-John S, et al. Novel pathogenic mechanism of microbial metalloproteinases: liberation of membrane-anchored molecules in biologically active form exemplified by studies with the human interleukin- 6 receptor. Infect Immun 1996;64:3646-51.

3 Fagerhol MK, Andersson KB, Naess-Andresen CF, et al. Calprotectin (the L1 leucocyte protein). In: Smith VL Dedman JR. eds. Stimulus response coupling: the role of intracellular calcium-binding proteins. Boca Raton: CRC Press, 1990:187-210

4 Johne B, Fagerhol MK, Lyberg T, et al. Functional and clinical aspects of the myelomonocyte protein calprotectin. Mol Pathol 1997;50:113-23.

5 Steinbakk M, Naess-Andresen CF, Lingaas E, et al. Antimicrobial actions of calcium binding leucocyte L1 protein, calprotectin. Lancet 1990;336:763-5.

6 Loomans HJ, Hahn BL, Li QQ, et al. Histidine-based zincbinding sequences and the antimicrobial activity of calprobinding sequences and the antimicro
tectin. $\mathcal{F}$ Infect Dis 1998;177:812-14.

7 tectin. F Infect Dis 1998;177:812-14. bial activity of calprotectin isolated from human empyema bial activity of calprotectin isolated from human empyema
fluid supernatants. Clin Immunol Immunopathol 1995;76: 285-90.
8 Sohnle PG, Hunter MJ, Hahn B, et al. Zinc-reversible antimicrobial activity of recombinant calprotectin (migration inhibitory factor-related protein 8 and 14). F Infect Dis 2000;182:1272-5.

9 Yui S, Mikami M, Yamazaki M. Induction of apoptotic cell death in mouse lymphoma and human leukemia cell lines by a calcium-binding protein complex, calprotectin, derived from inflammatory peritoneal exudate cells. $7 \mathrm{Leu}$ koc Biol 1995;58:650-8.

10 Himelstein BP, Canete-Soler R, Bernhard EJ, et al. Metalloproteinases in tumor progression: the contribution of MMP-9. Invasion Metastasis 1994/5;14:246-58.

11 Nelson AR, Fingleton B, Rothenberg ML, et al. Matrix metalloproteinases: biologic activity and clinical implications. F Clin Oncol 2000;18:1135-49.

12 Rucklidge GJ, Milne G. A radiolabel-release microwell assay for proteolytic enzymes present in cell culture media. Anal Biochem 1990;185:265-9

13 Dale I, Fagerhol MK, Naesgaard I. Purification and partial characterization of a highly immunogenic human leukocyte protein, the L1 antigen. Eur 7 Biochem 1983;134:1-6.

14 Ratnikov B, Deryugina E, Leng J, et al. Determination of matrix metalloproteinase activity using biotinylated gelatin. Anal Biochem 2000;286:149-55.

15 Ito A, Mukaiyama A, Itoh Y, et al. Degradation of nterleukin 1 beta by matrix metalloproteinases. $f$ Biol Chem 1996;271:14657-60.

16 Schonbeck U, Mach F, Libby P. Generation of biologically active IL-1 beta by matrix metalloproteinases: a novel caspase-1-independent pathway of IL-1 beta processing. 7 Immunol 1998;161:3340-6.

17 Haro H, Crawford HC, Fingleton B, et al. Matrix metalloproteinase-7-dependent release of tumor necrosis factor-alpha in a model of herniated disc resorption. $\mathcal{f}$ Clin Invest 2000;105:143-50.

18 Powell WC, Fingleton B, Wilson CL, et al. The metalloproteinase matrilysin proteolytically generates active soluble Fas ligand and potentiates epithelial cell apoptosis. Curr Biol 1999;9:1441-7.

19 Imai K, Hiramatsu A, Fukushima D, et al. Degradation of decorin by matrix metalloproteinases: identification of the cleavage sites, kinetic analyses and transforming growth factor-beta 1 release. Biochem 7 1997;322:809-14.

20 Sohnle PG, Hahn BL, Santhanagopalan V. Inhibition of Candida albicans growth by calprotectin in the absence of direct contact with the organisms. F Infect Dis 1996;174: 1369-72.

21 Yui S, Mikami M, Tsurumaki K, et al. Growth-inhibitory and apoptosis-inducing activities of calprotectin derived from inflammatory exudate cells on normal fibroblasts: regulation by metal ions. F Leukoc Biol 1997;61:50-7.

22 Fagerhol MK, Dale I, Andersson T. Release and quantitation of a leucocyte derived protein (L1). Scand F Haematol $1980 ; 24: 393-8$ 